Revista Brasileira de Ensino de Física, v. 28, n. 3, p. 257-258, (2006)

www.sbfisica.org.br

\title{
Editorial
}

\section{Um tributo a Boltzmann no centenário de sua morte}

É inacreditável como os resultados nos parecem naturais e simples uma vez descobertos, e quão difíceis são os caminhos que a eles conduzem enquanto ainda não descobertos. Do mesmo modo a dirigibilidade dos aeroplanos, uma vez conhecida, será facilmente obtida pelas mãos de técnicos. Inventada, porém ela só poderá ser por um gênio de primeira grandeza. E este inventor não deverá ser apenas um gênio, ele tem que ser também um herói. Só a duras penas poder-se-á desvendar os segredos dos elementos ainda não conquistados. Apenas aqueles que possuem a bravura de confiar sua vida a estes novos elementos $e$ a arte de vagarosamente se esquivar de suas armadilhas terá a chance de derrotar o dragão que ainda hoje esconde do homem o segredo desta descoberta. O inventor do aeroplano manobrável obrigatoriamente seguirá o exemplo do maior de todos os descobridores, Cristóvão Colombo, que não apenas pala sua bravura, mas também pela sua intuição definiu o exemplo a ser seguido por todos os descobridores do futuro. "Se não colocares sua vida na empreitada, nunca atingirás grandes objetivos". Deixe que aqueles que não conhecem suficientemente as maravilhas da tecnologia do nosso século riam das tentativas de voar.

Palavras premonitórias pronunciadas por Ludwig Boltzmann em conferência de 1894. Infelizmente, Boltzmann morreu um pouco antes de Santos Dumont realizar o primeiro bem sucedido vôo com o 14-bis em 23 de outubro de 1906.

A RBEF tem o prazer de apresentar a seus leitores uma coletânea de artigos em homenagem a Ludwig Boltzmann, um dos fundadores da mecânica estatística, por ocasião do centenário de sua morte. Como salientado por físicos e historiadores, os escritos técnicos de Boltzmann eram densos e difíceis exigindo além de conhecimento a argúcia do leitor. Optamos então pela publicação de duas palestras. Na primeira Boltzmann apresenta suas idéias sobre o significado das teorias físicas, em especial, da mecânica estatística, Na outra, demonstra todo seu interesse pelas viagens aéreas e especula sobre o futuro da aviação. A descoberta deste texto, cujo excerto abre este editorial, por Sílvio Dahmen, é fato marcante para nós por coincidir com as celebrações do centenário do vôo do 14 bis.

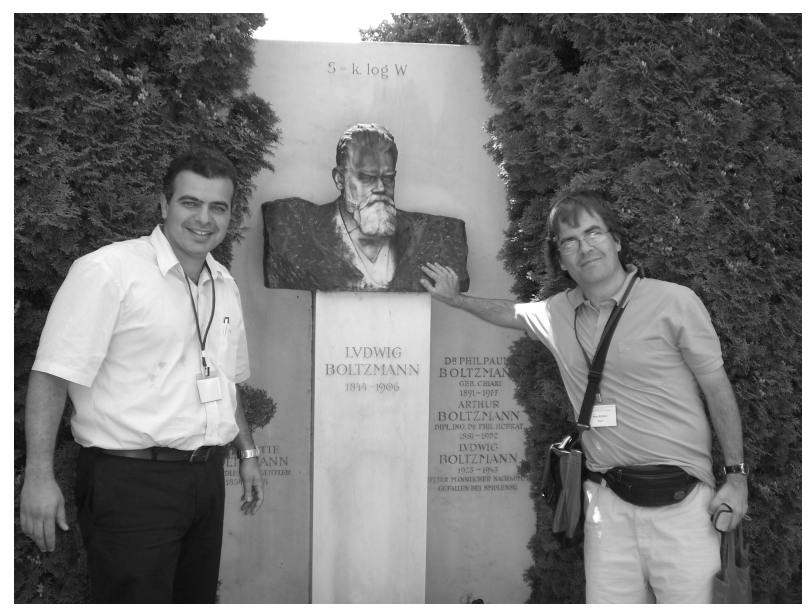

Rodrigo Capaz (UFRJ) à esquerda e Peter Schulz (Unicamp) em visita ao ao túmulo de Boltzmann em Viena (2006). No topo a famosa fórmula com a constante $k$ que Boltzmann jamais escreveu. Quem o fez desta forma foi Planck (Foto tirada pelo editor).

Copyright by the Sociedade Brasileira de Física. Printed in Brazil. 
Muito nos honra a contribuição de Joel Lebowitz, um físico mundialmente consagrado e um marco na área de mecânica estatística. O historiador e filósofo Antonio Augusto Videira vai além da descrição da carreira acadêmica de Boltzmann para discutir suas idéias sobre física teórica, em geral, e mecânica estatística em particular. Cássio Laranjeiras e José Chiappin, também estudiosos da obra de Boltzmann, penetram no âmago do seu programa mecânico-estatístico ao discutir como as várias leituras do trabalho de Maxwell sobre teoria cinética influenciaram a criação de novos conceitos propostos por Boltzmann. Sérgio Volchan, com propriedade e rigor matemático, aborda aspectos da interpretação das idéias probabilísticas em mecânica estatística. Sílvio Dahmen descreve a obra de Boltzmann em seu contexto mais amplo, envolvendo não apenas seus trabalhos mais significativos que fundaram a mecânica estatística atual, mas também trabalhos menos conhecidos do nosso homenageado. Oportuno e indispensável para a ocasião é o artigo de Sílvio Dahmen acerca do interesse de Boltzmann com a incipiente "aeronáutica" do final do século XIX, trazendo ao público brasileiro a correspondência original de Boltzmann com Otto Lilienthal, o grande pioneiro da aviação na Alemanha.

Agradecemos a todos os colaboradores desta seção especial da RBEF pelos interessantes artigos que, sem dúvida, contribuirão para um conhecimento aprofundado da obra de Boltzmann, da mecânica estatística e de aspectos epistemológicos da ciência. Em especial nosso muito obrigado a Sílvio Dahmen, que, além dos artigos, traduziu dois dos escritos populares de Boltzmann; a maioria deles encontra-se em livro organizado por Antonio Augusto Videira (ver a resenha neste número).

Nelson Studart

Departamento de Física Universidade Federal de São Carlos 